УДК 796.325

doi: 10.15330/fcult.36.46-53

Наталія Нестеренко, Олександра Крюковська

\title{
АНАЛІЗ СИСТЕМИ ТРЕНУВАЛЬНОГО ПРОЦЕСУ СПОРТСМЕНОК З ПЛЯЖНОГО ВОЛЕЙБОЛУ В РІЧНОМУ МАКРОЦИКЛІ НА ЕТАПІ СПЕЦІАЛІЗОВАНОЇ БАЗОВОЇ ПІДГОТОВКИ
}

Мета. Розкрити особливості тренувального процесу юних спортсменок 14-15 років з пляжного волейболу у річному макроциклі на етапі спеціалізованої базової підготовки. Методи. Для реалізації мети дослідження використовували: аналіз науково-методичної літератури та планів підготовки юних волейболісток; педагогічне спостереження; оцінку технічної підготовленості; контрольні випробування; педагогічний експеримент; методи математичної статистики. Аналіз системи підготовки та особливості навчально-тренувального прочесу з пляжного волейболу в річному макрочиклі на етапі спеціалізованої базової підготовки проводився в спортивних школах міста у відповідності до діючих програм. Результати. Система тренувального процесу у пляжному волейболі на етапі спеціалізованої базової підготовки здійснюється на основі двох ичиклового річного макроциклу. При ичьому обсяг тренувальних занять складає 960 годин протягом року (20 годин на тиждень). Відтак, на теоретичну підготовку відведено 30 годин, загальну і спеціальну фізичну - 295, технічну - 324, тактичну - 150, змагальну - 135 і на тестування 26 годин. Двох ичиклова структура річного макроциклу складається 3 трьох періодів - підготовчого, змагального та перехідного. Перший ичикл охоплює 7 календарних місяців, другий - 5. До структури у відповідності до поставлених завдань увійшли: втягуючий, базові, передзмагальні, змагальні та відновлювальні мезочикли, втягуючі, ударні, модельні, змагальні та відновлювальні мікроцикли. Висновок. Встановлено, ще система підготовки юних волейболісток 14-15 років з пляжного волейболу здійснюється на підставі програм для ДЮСШ, СДЮШОР, ШВСМ Украӥни. На підставі аналізу навчального плану встановлено, що протягом першого цчиклу річного макроциклу на загальну фізичну підготовку витрачається 30-35\% від загального часу, об'єм технічної підготовки складає 35-40\%, а тактичної, ігрової та спеціальної фізичної підготовки - 25-35\%. У другому циклі річного макрочиклу загальнв фізична підготовка планується в обсязі 20-25\% від загального часу, технічна 30-35\%, а тактична, ігрова та спеціальна фізична - 40-50\%.

Ключові слова: пляжний волейбол, юні спортсменки, річний макрочикл підготовки.

The purpose of the study is to reveal the features of the training process of young athletes aged 14-15 in beach volleyball in the annual macrocycle at the stage of specialized basic training.Methods. To achieve the goal of the study used: analysis of scientific and methodological literature and training plans for young volleyball players; pedagogical observation; assessment of technical readiness; control tests; pedagogical experiment; methods of mathematical statistics. The analysis of the training system and features of the training process in beach volleyball in the annual macrocycle at the stage of specialized basic training was conducted in sports schools of the city in accordance with current programs. Thus, 30 hours were allocated for theoretical training, 295 for general and special physical training, 324 for technical training, 150 for tactical training, 135 for competitive training, and 26 hours for testing. The two-cycle structure of the annual macrocycle consists of three periods - preparatory, competitive and transitional. Results. The system of training process in beach volleyball at the stage of specialized basic training is carried out on the basis of two cyclic annual macrocycles. The volume of training sessions is 960 hours per year $(20$ hours per week). The first cycle covers 7 calendar months, the second -5 . The structure according to the tasks included: retracting, main, pre-competition, competitive and restorative mesocycles, retracting, shock, model, competitive and restorative microcycles. Conclusion. It is established that the system of training of young volleyball players of 14-15 years on beach volleyball is carried out on the basis of programs for CYSS, SDYUSHOR, SHVSM of Ukraine. Based on the analysis of the curriculum, it is established that during the first cycle of the annual macrocycle 30-35\% of the total time is spent on general physical training, the amount of technical training is 35-40\%, and tactical, game and special physical training - 25-35\%. У другому циклі річного макрочиклу загальна фізична підготовка планується в обсязі 20-25\% від загального часу, технічна 30-35\%, тактична, ігрова та спеціальна фізична підготовка - 40-50\%.

Keywords: beach volleyball, young sportswomen, annual training macrocycle.

Постановка проблеми та аналіз результатів останніх досліджень. Волейбол як вид спорту за останні кілька років зазнав значних змін, які пов'язані як 3 природним 
процесом розвитку гри, так і з кардинальними змінами в правилах, що відбулися у 90-ті роки. Все це суттєво вплинуло на змагальний і тренувальний процес спортсменів.

Поряд 3 класичним волейболом активно розвиваються такі різновиди гри, як пляжний волейбол, волейбол для осіб з інвалідністю [1].

Пляжний волейбол (beach volleyball) - порівняно молодий, надзвичайно динамічний і видовищний вид спорту, що закріпився в програмі Олімпійських ігор [6, 7]. Його стрімкий розвиток в багатьох країнах різних континентів, розширення програми європейських і світових чемпіонатів, успішний дебют на Олімпійських іграх в Атланті у 1996 році, неухильне збільшення призового фонду турнірів викликають загострення спортивної конкуренції на міжнародній арені, що сприяє підвищенню рівня майстерності гравців і зростанню популярності гри.

Сьогодні маємо значну кількість наукових досліджень щодо вдосконалення системи підготовки спортсменів у класичному волейболі $[1,2,8]$, а також у пляжному варіанті гри $[6,11,15]$. При цьому, тренери і спортсмени, в області пляжного волейболу відчувають значний дефіцит щодо науково-методичного забезпечення процесу підготовки спортсменів високого класу в пляжному волейболі. Це пов'язано, в першу чергу, зі специфікою навчально-тренувальної та змагальної діяльності в пляжному волейболі. Процес підготовки спортсменів високого класу в пляжному волейболі в сучасних умовах вимагає, обгрунтування, розробки і впровадження нових перспективних технологій i методик, комплексного вивчення проблем підготовки на основі аналітико-синтетичних підходів при провідній ролі специфіки змагальної діяльності $[3,12,16,17]$.

На підставі аналізу науково-методичної літератури визначено, що проблема стосовно особливостей планування навчального процесу на етапі спеціалізованої базової підготовки у пляжному волейболі $є$ актуальною.

Мета дослідження - розкрити особливості тренувального процесу юних спортсменок 14-15 років з пляжного волейболу у річному макроциклі на етапі спеціалізованої базової підготовки.

Методи дослідження. Для реалізації мети дослідження використовували: аналіз науково-методичної літератури та планів підготовки юних волейболісток; педагогічне спостереження; оцінку технічної підготовленості; контрольні випробування; педагогічний експеримент; методи математичної статистики. Аналіз системи підготовки та особливості навчально-тренувального процесу з пляжного волейболу в річному макроциклі на етапі спеціалізованої базової підготовки проводився в ДЮСШ, СДЮШОР, ШВСМ МСДЮШОР з волейболу м. Дніпра у відповідності до діючих програм.

Результати дослідження. Встановлено, що планування фізичних навантажень здійснюється у відповідності до календаря основних змагань, які проводяться у травні та вересні. Тому загальна структура річного тренувального процесу на етапі спеціалізованої базової підготовки у пляжному волейболі має двох циклову структуру (табл. 1).

Обсяг тренувальних занять на рік відповідно до програми складає 20 годин на тиждень і 960 годин на рік. Щодо розподілу годин на різні види підготовки, то на теоретичну підготовку відведено 30 годин, фізичну - 295 годин (30,7\%), технічну - 324 години $(33,7 \%)$, тактичну - 150 годин, змагальну - 135 годин $(14 \%)$ і на тестування 26 годин. Кожен цикл незалежно від його тривалості, складається 3 трьох обов'язкових періодів - підготовчого, змагального та перехідного. На співвідношення тривалості цих періодів впливають ряд чинників - календар змагань, кваліфікація спортсменів, стать, вік тощо. 
Двох циклова структура річної підготовки волейболісток 14-15 років

Таблиия 1

у пляжному волейболі

\begin{tabular}{|c|c|c|c|c|c|c|c|c|c|c|c|}
\hline \multirow{31}{*}{ 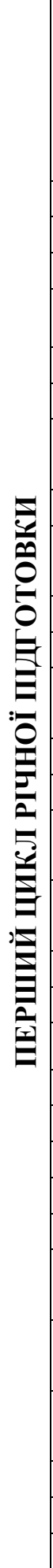 } & \multirow{4}{*}{\begin{tabular}{|l} 
\\
总 \\
Втягуючий \\
Втягуючий \\
Втягуючий \\
\end{tabular}} & \multirow{5}{*}{ 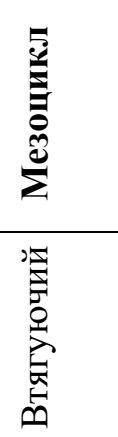 } & \multicolumn{2}{|l|}{ 高 } & \multirow{5}{*}{ 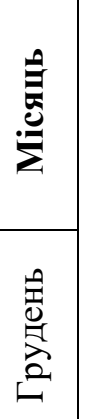 } & & \multirow{3}{*}{$\begin{array}{l}5 \\
\text { Ударний } \\
\text { Ударний } \\
\end{array}$} & \multirow{5}{*}{ 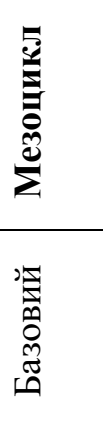 } & \multicolumn{2}{|l|}{ 告 } & \multirow{5}{*}{ 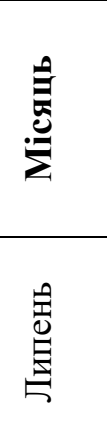 } \\
\hline & & & \multirow{4}{*}{ 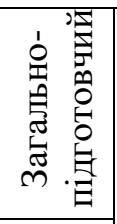 } & \multirow{17}{*}{ 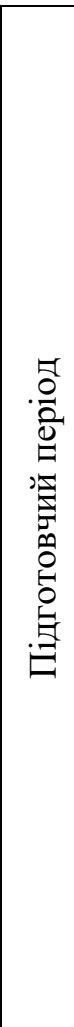 } & & & & & & & \\
\hline & & & & & & & & & Е & & \\
\hline & & & & & & & Відновлювальний & & $\underset{D}{ \pm}$ & & \\
\hline & Втягуючий & & & & & & Ударний & & 空 & $\frac{0}{2}$ & \\
\hline & Ударний & \multirow{5}{*}{ 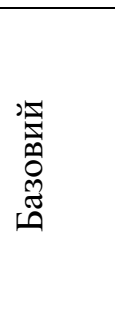 } & \multirow{13}{*}{ 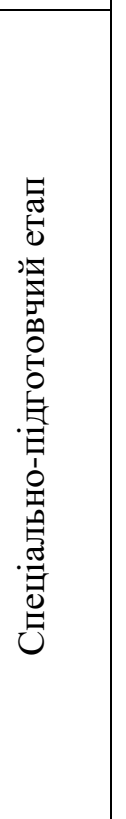 } & & \multirow{5}{*}{ 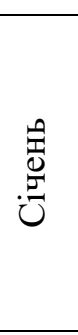 } & \multirow{5}{*}{ 蛋 } & Ударний & \multirow{6}{*}{ 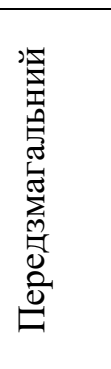 } & : & $\underset{\Xi}{E}$ & \\
\hline & Ударний & & & & & & Відновлювальний & & . & 䲶 & \\
\hline & $\begin{array}{l}\text { Відновлюваль } \\
\text { ний }\end{array}$ & & & & & & Ударний & & 章 & 离 & \\
\hline & Ударний & & & & & & Ударний & & .气్త్ర & 其 & \\
\hline & $\begin{array}{l}\text { Відновлюваль } \\
\text { ний }\end{array}$ & & & & & & Модельний & & 光 & & 吾 \\
\hline & Ударний & \multirow{4}{*}{ 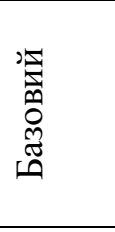 } & & & \multirow{4}{*}{$\begin{array}{l}\text { 䍖 } \\
\text { 量 }\end{array}$} & \multirow{3}{*}{ 它 } & Модельний & & & & ن \\
\hline & Ударний & & & & & & Ударний & \multirow{5}{*}{ 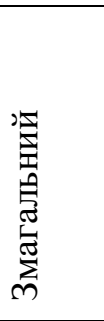 } & \multirow{5}{*}{ 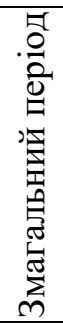 } & & \multirow{5}{*}{ 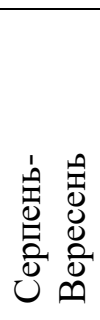 } \\
\hline & $\begin{array}{l}\text { Відновлюваль } \\
\text { ний }\end{array}$ & & & & & & Модельний & & & & \\
\hline & Ударний & & & & & \multirow{8}{*}{ לָ } & Модельний & & & & \\
\hline & Ударний & \multirow{4}{*}{ 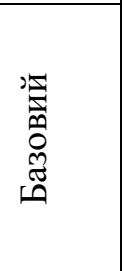 } & & & \multirow{4}{*}{ 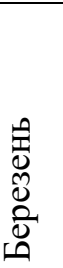 } & & Змагальний & & & & \\
\hline & Ударний & & & & & & Змагальний & & & & \\
\hline & $\begin{array}{l}\text { Відновлюваль } \\
\text { ний }\end{array}$ & & & & & & Відновлювальний & 实吗 & & & $\hat{\mathrm{A}}$ \\
\hline & Ударний & & & & & & Відновлювальний & 兽 壱 & .7. & & $\underset{\oplus}{\vec{\oplus}}$ \\
\hline & Ударний & \multirow{4}{*}{ 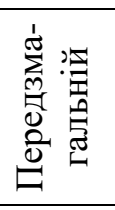 } & \multirow{8}{*}{ 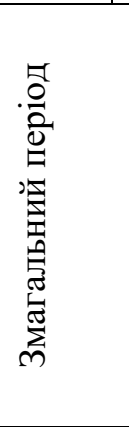 } & & & & Відновлювальний & 蛋 & 巳 & & 䒘 \\
\hline & Ударний & & & & 跑 & & Відновлювальний & $\infty$ & 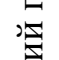 & & \\
\hline & Модельний & & & & sens & & Відновлювальний & &.$\Xi$ & & \\
\hline & Модельний & & & & & & Відновлювальний & 올 聣 & 希 & & త్త్త \\
\hline & Модельний & 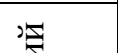 & & & & & Відновлювальний & 咅 & ?2 & & E \\
\hline & Змагальний & 壳 & & & $\hat{\theta}$ & & Втягуючий &.$\vec{N}$ & & & $\stackrel{5}{E}$ \\
\hline & Змагальний & 昜 & & & 兽 & & Втягуючий & & & & 气 \\
\hline & $\begin{array}{l}\text { Відновлю- } \\
\text { вальний }\end{array}$ & $\sum_{\text {ले }}^{\bar{T}}$ & & & ق & & & & & & \\
\hline & $\begin{array}{l}\text { Відновлю- } \\
\text { вальний }\end{array}$ & & & & & & & & & & \\
\hline & $\begin{array}{l}\text { Відновлю- } \\
\text { вальний }\end{array}$ & 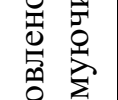 & 量 & & 害 & & & & & & \\
\hline & Втягуючий & 蛋志 & $\overrightarrow{0}$ & & $\frac{\hat{\theta}}{2}$ & & & & & & \\
\hline & Втягуючий & $\ddot{n} \cdot \vec{E}$ & & & & & & & & & \\
\hline & Втягуючий & & & & & & & & & & \\
\hline
\end{tabular}

Структура річної підготовки пов'язана безпосередньо з системою організації тренувальних навантажень, що передбачає певний порядок і черговість введення в тренування обсягів навантажень різної спрямованості, створення умов, за яких попередні 
навантаження забезпечують сприятливий морфо-функціональний, психологічний фон для підвищення тренувального впливу наступних $[4,5]$.

Підготовчий період відповідає фазі становлення спортивної форми. У змагальний період створюють необхідні умови для його збереження і досягнення запланованих спортивних результатів. Перехідний період супроводжується тимчасовою втратою спортивної форми. У пляжному волейболі на етапі спеціалізованої базової підготовки протягом одного року два (весінній і осінній) змагальних сезони, і тому планування спортивного тренування передбачає в межах одного року.

Загальним завданням підготовчого періоду $є$ підготовка гравців до найвищих спортивних досягнень, які вони повинні здобути на майбутніх найголовніших змаганнях. Для цього необхідні: високий рівень адаптації організму гравців до великих психофізичних навантажень; належний розвиток головних фізичних якостей; досконалість техніко-тактичної підготовленості.

Підготовчий період в спортивній практиці пляжного волейболу поділяється на два етапи: загально-підготовчий та спеціально-підготовчий. При цьому, в першому циклі плануються загально-підготовчий та спеціально-підготовчий етапи, а в другому лише спеціально-підготовчий. В даний період здійснюється досягнення максимально можливого рівня спеціальної фізичної працездатності.

Спеціально-підготовчий етап характеризується різким зниженням обсягу навантажень загальної фізичної підготовки і збільшенням кількості швидкісних та швидкісно-силових компонентів навантажень аеробно-анаеробної спрямованості, виконуваних з використанням спеціальних вправ. Після поступового зменшення цих навантажень досягається максимально можливий рівень анаеробної продуктивності, а також психічної підготовленості.

Високий рівень показника фізичної працездатності досягається протягом трьох тижнів за рахунок планування великого обсягу навантажень загальної фізичної підготовки, але тільки аеробно-анаеробної спрямованості. Досягнення максимально можливого рівня загальної витривалості здійснюється за рахунок кросової підготовки, яку планують протягом двох місяців у значному обсязі.

Змагальний період характеризується досягненням максимальної злагодженості всіх компонентів функціональної підготовленості, необхідної для ефективної реалізації досягнутої спортивної форми.

Основними завданнями перехідного періоду $є$ повноцінне відновлення після тренувальних і змагальних навантажень річного макроциклу, підтримка на певному рівні тренованості для забезпечення оптимальної готовності спортсмена до початку наступного періоду підготовки. Особлива увага повинна бути звернена на повноцінне фізичне і психічне відновлення. Ці завдання визначають тривалість перехідного періоду, підбір засобів і методів, динаміку навантажень. Тривалість перехідного періоду коливається від 3-4-х до 6-8-ми тижнів і залежить від системи планування тренування протягом року, тривалості змагального періоду, складності та відповідальності основних змагань, індивідуальних здібностей спортсменів.

Тривалість першого циклу складає 7 місяців та включає 7 мезоціклів, які пов'язані з особливостями становлення спортивної форми: втягуючий - базовий - базовий базовий - передзмагальний - змагальний - відновлювально-підтримуючий. Протягом першого циклу планується 7 втягуючих, 11 ударних, 7 відновлювальних, 3 модельних та 2 змагальних мікроцикли, які вирішують конкретні завдання.

На фізичну підготовку витрачається 30-35\% загального обсягу. Об'єм технічної підготовки складає 35-40\% (головна спрямованість - удосконалення індивідуальної майстерності). Тактичній, ігровій та спеціальній підготовки відводиться 25-35\% часу. 
На першому циклі річної підготовки основна увага приділяється розвитку загальної та спеціальної фізичної підготовки, які забезпечується шляхом підбору спеціально-підготовчих вправ. Наприкінці першого циклу річної підготовки робиться акцент на швидкісно-силову, технічну, тактичну та психічну підготовленість.

Особливе місце в тренувальному процесі другого циклу відводиться розвитку швидкісно-силових здібностей та анаербно-аеробної працездатності, головним чином за рахунок планування специфічних вправ для волейболісток на піску, які паралельно сприяють структурно-функціональні перебудові головних скелетних м'язів та сприяють розвитку стрибучості.

Відомо, що морфо-функціональні властивості організму спортсмена та закономірності їх вдосконалення $є$ основою формування його функціональної підготовленості. Функціональна підготовленість - це рівень тренованості і злагодженості взаємодії чотирьох iï компонентів, а саме: психічного, нейродинамічного, енергетичного і рухового $з$ урахуванням етапу підготовки спортсмена. У фізіології спорту найбільш вивченим, $є$ енергетичний компонент. Психічний і особливо нейродинамічний компоненти тільки починають привертати увагу фізіологів, а руховий компонент став предметом педагогіки і біомеханіки.

У другому циклі тренувального процесу важливими $є$ навантаження, які забезпечують накопичення енергетичного потенціалу. Але його величина формується завдяки оптимальному обсягу навантаження, точніше раціональному співвідношенню тривалості, частоти та інтенсивності навантаження) як під час першого, так і другого циклів річної підготовки [13].

Тривалість другого циклу складає 35 місяців та включає 5 мезоциклів, які пов'язані з особливостями підтримки та підвищення спортивної форми: базовий - перед змагальний - змагальний - відновлювальний - відновлювальний. Протягом другого циклу планується 7 ударних, 4 модельних, 2 змагальних, 9 відновлювальних та 2 втягуючих мікроцикли наприкінці між річного перехідного періоду.

В другому циклі річного макроциклу на фізичну підготовку витрачається 20-25\% загального часу. Об'єм технічної підготовки складає 30-35\% (головна спрямованість удосконалення індивідуальної майстерності спортсменок). Тактична, ігрова та спеціальна підготовка займає 40-45\% часу. Як бачимо, відбувається перерозподіл часу, насамперед зменшення величини загальної фізичної підготовки та збільшення обсягу тактичної, ігрової й спеціальної фізичної спрямованості тренувального процесу.

Суттєвою особливістю $є$ те, що у другому циклі річної підготовки робиться акцент на підвищення спеціальної витривалості, а також вдосконалення необхідних психічних якостей та функціональних властивостей центральної нервової системи (збудливості, рухливості, стійкості, нейроендокринної мобілізації вегетативних функцій) за рахунок планування змагального режиму підготовки, коли на перший план виступають якості мобілізаційної готовності спортсмена.

При плануванні змагальних навантажень враховувались обставини щодо розвитку високого рівня м'язової витривалості, яка зберігається не більше 1,5-2 місяців.

Завдання другого підготовчого періоду було спрямоване на вдосконалення підготовленості команди в цілому, а саме формування колективної гри. Для успішного виступу на змаганнях, гравцям планували безлічі прийомів гри великої інтенсивності та умінь, які є доцільними та ефективними в конкретній обстановці, яка виникає на майданчику під час гри. Наприкінці другого підготовчого періоду проводилася двостороння гра за 7-10 днів до початку календарних ігор. Після цього велась цілеспрямована робота над усуненням недоліків та удосконалення індивідуальної майстерності. 
Основним завданням другого перехідного періоду є забезпечення повноцінного активного відпочинку і разом з тим збереження певного рівня тренованості, необхідного для початку нового циклу тренування. У цей період спортивна форма тимчасово втрачається; вся робота повинна бути спрямована на ліквідацію наслідків стомлення, що виникає протягом тривалого тренувального процесу. Зміст фізичної, техніко-тактичної підготовки підпорядкований вирішенню цього завдання. Активний відпочинок організовується як за рахунок переходу на інші види фізичної діяльності, так і за рахунок зміни обстановки та зовнішніх умов.

Дискусія. Аналіз спеціальної наукової літератури показав, що існує багато наукових робіт з проблем удосконалення системи підготовки у класичному волейболі $[1,4,5,6,15,17]$, але недостатньо уваги приділяється вивченню та вдосконаленню системи підготовки спортсменів, які займаються в пляжному волейболі. Це можна пояснити тим, що пляжний волейбол є молодим видом спорту в Україні, який включений в програму Олімпійських ігор. В Україні пляжний волейбол набув свого інтенсивного розвитку на початку XXI століття. Як зазначають науковці $[2,9,12]$, рівень розвитку фізичних якостей впливає на процес навчання та вдосконалення технічної майстерності виконання змагальних вправ, тому сьогодні тренери акцентують увагу у навчальнотренувальному процесі на плануванні загальної та спеціальної фізичної підготовленості спортивної підготовки з урахуванням їх функцій, які виконують волейболісти на піску. Тому фізичне навантаження у навчально-тренувальному процесі повинно бути спрямоване на вдосконалення фізичної підготовленості спортсменів-волейболістів у поєднанні 3 вдосконаленням технічної майстерності, зокрема на етапі спеціалізованої базової підготовки

Висновок. Встановлено, що система підготовки юних волейболісток 14-15 років 3 пляжного волейболу здійснюється на підставі програм для ДЮСШ, СДЮШОР, ШВСМ України. На підставі аналізу навчального плану встановлено, що протягом першого циклу річного макроциклу на загальну фізичну підготовку витрачається 30-35\% від загального часу, об'єм технічної підготовки складає $35-40 \%$, а тактичної, ігрової та спеціальної фізичної підготовки - 25-35\%. У другому циклі річного макроциклу загальнв фізична підготовка планується в обсязі 20-25\% від загального часу, технічна 30-35\%, а тактична, ігрова та спеціальна фізична - 40-50\%.

1. Беляев АВ, Булыкин ЛВ. Волейбол: теория и методика тренировки. М.: Физкультура и спорт. 2007. $98 \mathrm{c.}$

2. Горчанюк ЮА. Техническая подготовка спортсменов в пляжном волейболе на основе биомеханических моделей прыжков и перемещений: дис. ... канд.наук физ. воспитанию и спорту. 24.00.01. Харьковская гос. академия физической культуры. Харьков, 2004. 226 с.

3. Гунченко ВВ. Ефективність подач як вагомий фактор змагальної діяльності у пляжному волейболі. Фізична культура, спорт та здоров'я нації 2018; 6: 122-129.

4. Дорошенко ЭЮ, Цапенко ВА, Кушнир ГИ, Медведь МН. Комплексы физических упражнений для спортсменов в пляжном волейболе в подготовительном периоде подготовки. Физическое воспитание студентов творческих спеціальностей. 2004; 6: $28-34$.

5. Келлер ВС, Платонов ВМ. Теоретико-методичні основи підготовки спортсменів. Львів: Українська Спортивна Асоціація, 1992. 270 с.

6. Костюков ВВ, Чесноков ЮБ, Тимохин АВ. Пляжный волейбол: методическое пособие. Москва, 1997. $96 \mathrm{c}$.

7. Кропивницкая ТА, Войтова ОВ. Развитие пляжного волейбола в современных условиях международного спортивного движения. Probleme actuale privind perfectionarea sistemului de invatamint in domeniul culturii fizice : materialele conferintei stiintifice international. Chisinau: USEFS, 2014; 208-211.

8. Кудряшов $\mathrm{CB}$. Побудова і контроль тренувального процесу волейболісток на етапі спеціалізованої базової підготовки: автореф. дис. ... канд. фіз. виховання і спорту: 24.00.0. Харківська держ. академія фізичної культури. Харків, 2004. 22 с. 
9. Осадчий ОВ. Вплив спеціальних засобів навантаження на стан технічної майстерності волейболістів різних вікових груп: автореф. дис. ... канд.наук з фіз.виховання і спорту: 24.00.01 / Харківська держ. академія фізичної культури. Харків, 2007. 23 с.

10. Пляжний волейбол. Навчальна програма для ДЮСШ, СДЮШОР, ШВСМ / під. ред. М.П.Піменова, I.М.Тищенко. К.: Республіканський науково-методичний кабінет Державного комітету України 3 питань фізичної культури і спорту. 2003. 155 с.

11. Рудковская ЕВ. Динамика нагрузок в макроцикле подготовки юных спортсменок, специализирующихся в пляжном волейболе. Вестник спортивной науки. 2007; 3: 3-7.

12. Соловей ОМ, Гунченко ВВ. Аналіз ефективності результатів змагальної діяльності у пляжному волейболі. Спортивний вісник Придніпров'я. 2018; 3: 126-130.

13. Уилмор ДжХ, Костилл ДЛ. Физиология спорта и двигательной активности. К.: Олимпийская литература, 1997. 504 с.

14. Хомберг С. Деякі поради з техніки і тактики пляжного волейболу. URL: http//lib/sported.ru.

15. Хёмберг С, Атанасиос Папагеоргиу. Пляжный волейбол. Global Coaching, 2019. 329 с.

16. Dimitrios G. Balasas, Kosmas Christoulas, Panagiotis Stefanidis, Efstratios Vamvakoudis, Theodoros M. Bampouras. The effect of beach volleyball training on muscle performance of indoor volleyball players. 2017;19. [Electronic resource]. Resource Access Mode:insight@cumbria.ac.uk.

17. Jonathan C. Reeser MD PhD, Roald Bahr MD PhD. Volleyball (The Handbook of Sports Medicine and Science). 3rd edition. Wiley-Blackwell, 2014. 242 p.

\section{References}

1. Belyayev AV, Bulykin LO. Voleybol: teoriya i metodika trenirovki. M .: Fizkul'tura i sport. 2007.98 s.

2. Gorchanyuk YUA. Tekhnicheskaya podgotovka sportsmenov v plyazhnom voleybole na osnove biomekhanicheski modeley pryzhkov i peremeshcheniy: dis ... kand.nauk po fiz.vospitaniyu i sporta. 24.00.01 Khar'kovskaya gos.akademiya fizicheskoy kul'tury. Khar'kov, 2004. 226 s.

3. Hunchenko VV. Efektyvnist' podach yak vahomyy faktor zmahal'noyi diyal'nosti u plyazhnomu voleyboli. Fizychna kul'tura, sport ta zdorov'ya natsiyi 2018; 6: 122-129.

4. Doroshenko, EYU., Tsapenko, VA., Kushnir, GI., Medved', MN. Kompleksy fizicheskikh uprazhneniy dlya sportsmenov v plyazhnom voleybole v podgotovitel'nom periode podgotovki. Fizicheskoye vospitaniye studentov tvorcheskikh spetsíal'nostey. 2004; 6: 28-34.

5. Keller VS, Platonov VM. Teoretyko-metodychni osnovy pidhotovky sport·smeniv. L'viv: Ukrayins'ka Sportyvna Asotsiatsiya, 1992. $270 \mathrm{~s}$.

6. Kostyukov VV, Chesnokov YUB, Timokhin AV. Plyazhnyy voleybol: metodicheskoye posobiye. Moskva, $1997.96 \mathrm{~s}$.

7. Kropivnitskaya TA, Voytova OV. Razvitiye plyazhnogo voleybola v sovremennykh usloviyakh mezhdunarodnogo sportivnogo dvizheniya. Probleme actuale privind perfectionarea sistemului de invatamint in domeniul culturii fizice : materialele conferintei stiintifice international. Shisinau: USEFS, 2014; 208-211.

8. Kudryashov YEV. Pobudova i kontrol' trenuval'noho protsesu voleybolistok na etapi spetsializovanoyi bazovoyi pidhotovky: avtoref. dys. ... kand. z fiz. vykhovannya i sportu: 24.00 .0 / Kharkivs'ka derzh. akademiya fizychnoyi kul'tury. Kharkiv, 2004. $22 \mathrm{~s}$.

9. Osadchyy OV. Vplyv spetsial'nykh zasobiv navantazhennya na stan tekhnichnoyi maysternosti voleybolistiv riznykh vikovykh hrup: avtoref. dys. ... kand.nauk z fiz.vykhovannya i sportu: 24.00.01 / Kharkivs'ka derzh. akademiya fizychnoyi kul'tury. Kharkiv, 2007. 23 s.

10. Plyazhnyy voleybol. Navchal'na prohrama dlya DYUSSH, SDYUSHOR, SHVSM / pid. red. M.P. Pimenova, I.M. Tyshchenko. K.: Respublikans'kyy naukovo-metodychnyy kabinet Derzhavnoho komitetu Ukrayiny z pytan' fizychnoyi kul'tury i sportu. 2003. $155 \mathrm{~s}$.

11. Rudkovskaya YEV. Dinamika nagruzok v makrotsikle podgotovki yunykh sportsmenok, spetsializiruyushchikhsya v plyazhnom voleybole. Vestnik sportivnoy nauki. 2007; 3: 3-7.

12. Solovey OM, Hunchenko VV. Analiz efektyvnosti rezul'tativ zmahal'noyi diyal'nosti u plyazhnomu voleyboli. Sportyvnyy visnyk Prydniprov’ya. 2018; 3: 126-130.

13. Uilmor Dzh KH, Kostill D L. Fiziologiya sporta i dvigatel'noy aktivnosti. K.: Olimpiyskaya literatura, 1997. $504 \mathrm{~s}$.

14. Khomberh S. Deyaki porady z tekhniky i taktyky plyazhnoho voleybolu. URL: http//lib/sported.ru.

15. Khomberg S, Atanasios Papageorgiu. Plyazhnyy voleybol. Global Coaching, 2019. 329 s.

16. Dimitrios G. Balasas, Kosmas Christoulas, Panagiotis Stefanidis, Efstratios Vamvakoudis, Theodoros M. Bampouras. The effect of beach volleyball training on muscle performance of indoor volleyball players. 2017. №19. [Electronic resource]. Resource Access Mode:insight@cumbria.ac.uk.

17. Jonathan C. Reeser MD PhD, Roald Bahr MD PhD. Volleyball (The Handbook of Sports Medicine and Science). 3rd edition. Wiley-Blackwell, 2014. 242 p. 
Цитування на цю статтю:

Нестеренко НА, Крюковська ОС. Аналіз системи тренувального процесу спортсменок 3 пляжного волейболу в річному макроциклі на етапі спеціалізованої базової підготовки. Вісник Прикарпатського університету. Серія: Фізична культура. 2020 Листоп 24; 36: 48-53

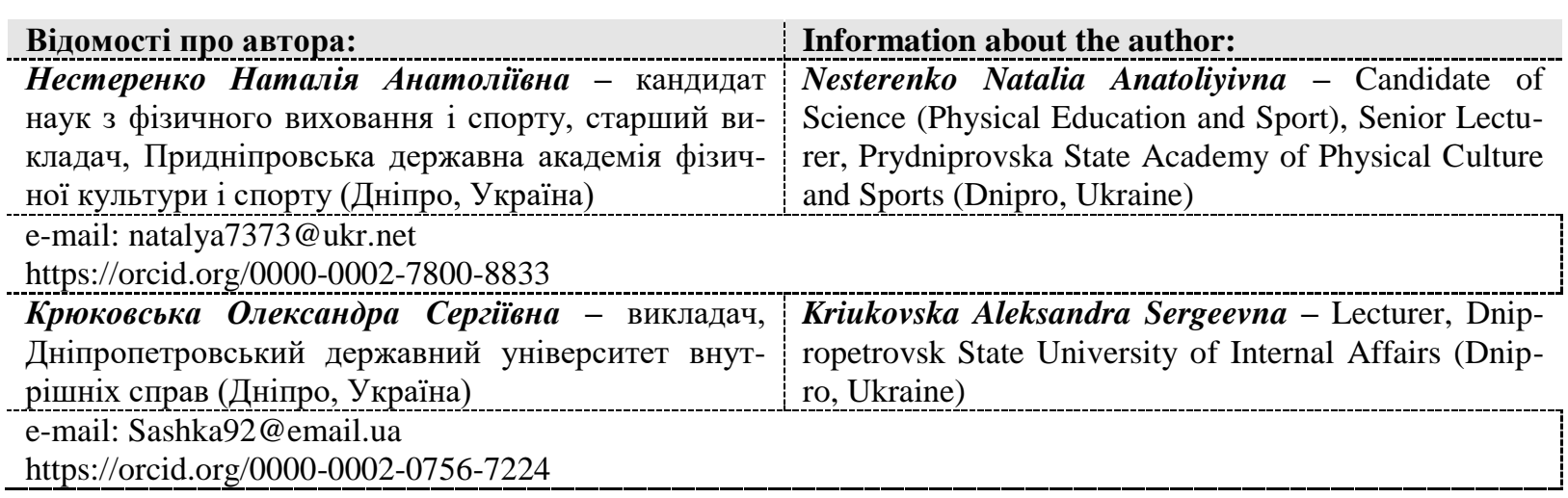

УДК 615.838+616-036.82+616.24

Роман Сарапук doi: 10.15330/fcult.36.53-57

\title{
ЕФЕКТИВНІСТЬ ЗАСТОСУВАННЯ ПЛАВАННЯ ДЛЯ ВІДНОВЛЕННЯ ФУНКЦІОНАЛЬНОГО СТАНУ КАРДІОРЕСПІРАТОРНОЇ СИСТЕМИ ПІСЛЯ ПЕРЕНЕСЕНИХ ЗАПАЛЕНЬ ЛЕГЕНЬ
}

\begin{abstract}
Мета. Встановити вплив занять плаванням на відновлення функціональних резервів кардіореспіраторної системи після перенесених запальних захворювань легень. Методи. У дослідженні взяли

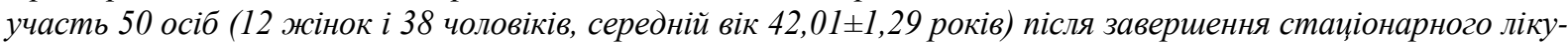
вання з приводу запальних захворювань легень в пульмонологічному відділенні Івано-Франківського обласного фтизіопульмонологічного иентру. 3 а погодженням з лікуючими лікарями вони були скеровані у санаторії “Алмаз” $i$ “Кристал (м. Трускавецьь) де основним групам (ОГ) у кількості 25 осіб чоловічої $і 6$ жіночої статі було створено умови для щзоденних занять плаванням протягом 18 днів. Тривалість кожного заняття складала 45 хвилин, а обсяг фізичного навантаження - 400-800 м при ЧСС 120-140 уд/хв. Контрольні групи протягом перебування в санаторії плавання не використовували. Для оцінки основних показників функиії зовнішнього дихання використовувався комп'ютерний спірометр Microspiro HI-501. Визначення загальної фізичної прачездатності здійснювали за допомогою проби Джеймса. Обстеження здійснювали двічі (до початку і після завершення циклу занять плаванням). Результати. Порівняльний аналіз змін середніх значень дихального об'єму і життєвої ємності легень контрольної й основної групи чоловіків свідчить про те, щуо в основній групі иі показники зовнішнього дихання перевищують дані групи контролю на 10,9\% і 4,0\% відповідно (p<0,05). Аналіз засвідчує, Щодо жінок, то величини дихального об'єму та життєвої ємності легень основної групи наприкінці занять зросли у порівнянні з групою контролю на 5,0\% і 12,4\% відповідно. Вірогідні зміни виявлені також і в показниках хвилинного об' $є м у$ дихання, форсованого об'єму дихання та пікової швидкості видиху як у чоловіків, так $і$ в жінок. Висновок. Застосування плавання у відновному періоді осіб, які перенесли запальні захворювання дихальної системи забезпечує нормалізацію функціонування як дихальної, так і серцево-судинної системи, щзо опосередковано свідчить про нормалізачію механізмів нейрогуморальної регуляиії функцій організму.
\end{abstract}

Ключові слова: плавання, запальні захворювання легень, функиіональний стан.

Aim. To establish the influence of swimming on the restoration of functional reserves of the cardiorespiratory system after inflammatory lung diseases. Methods. The study involved 50 people (12 women and 38 men, mean age $42.01 \pm 1.29$ years) after inpatient treatment for inflammatory lung disease in the pulmonology department of the Ivano-Frankivsk Regional Phthisiopulmonology Center. In agreement with the attending physicians, they were sent to the sanatoriums "Diamond" and "Crystal" (Truskavets) where the main groups of 25 males and 6 females were created conditions for daily swimming for 18 days. The duration of each session was 45 minutes, and the amount of physical activity - 400-800 m at a heart rate of 120-140 b/m. Control groups were not used during their stay in the swimming sanatorium. A computer spirometer was used to assess the main 